\title{
持続可能な成長・開発にむけた 良質なガバナンス
}

一国際行政学会カンファレンスの報告一

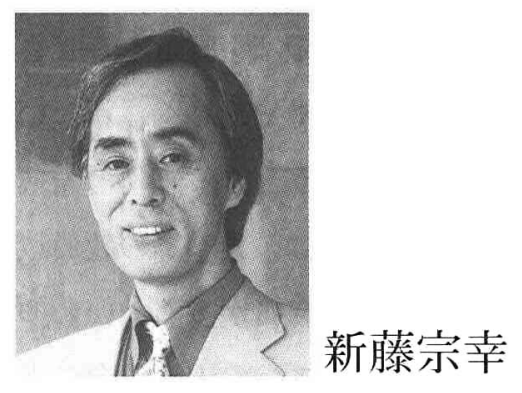

\section{国} $>\quad$ 際

\section{$\checkmark$ 源}

\section{$\checkmark$}

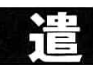

$\checkmark$
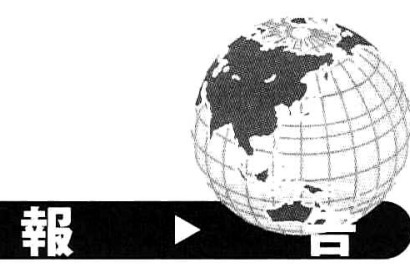

国際行政学会（IIAS）の第2回特別国際会議 は、2002年11月5日から9日にかけて、インドの ニューデリーで開催された。会場とされたアシ ヨカホテルは、国際的な観光資本によるホテル 立地が続くなかで、国営ホテルとして存続して きた。広大な敷地をもったコロニアル風の建物 には、よ゙こか安らぎを覚える。

とはいえ、2002年前半にインド・パキスタン 間の軍事的緊張が高まったことに加え、アフガ ニスタンでの戦争も終息をみていたおけではな い。ホテル内のコンベンションホール内外には 銃を構えた兵士が配置され、ものものしい警戒 体制がとられた。参加者は45力国と国連、 OECDなどの国際機関からの約300名であった。 当時の国際情勢を反映してか、実に印象的であ ったのは、国際行政学会の各種のカンファレン スに大勢出席するアメリカからの参加者が、わ
ずかに1人だったことである。ともあれ、イン ド政府の人事・苦情処理・年金省を主体とした 組織委員会は、ホスピタリティあふれる会議を 運営した。

\section{ガバナンスへの関心の高まり}

今回の会議の全体テーマは、「持続可能な成 長と開発のための良質なガバナンスを求めて」 であった。2001年7月のギリシャ・アテネでの 大会でもガバナンスの質的向上が主要テーマと されたが、このところ国際行政学会の理論的か つ実務的関心は、もっぱらガバナンスのあり方 におかれている。学問的概念としてガバナンス には、決して定まった理解があるわけではない。 ただし、「ガバメントからガバナンスへ」とい われるように、経済のグローバル化の進行する なかで、先進国、発展途上国のいずれに打いて 
も意思決定システムの改革と政策 ·事業の有効 性を高めることが問われている。とりわけ、国 際行政学会の参加国に発展途上国が多数を占め ることもあって、ガバナンスの質やその向上に 向けた改革方策への関心が高まっているといっ てよい。

基調報告に立ったのは南アフリカ共和国の行 政管理大臣である $\mathrm{G} \cdot \mathrm{F} \cdot$ モレキティ女史であ つた。彼女は1988年以来、南アフリカ共産党の 共同議長を務めているが、アパルトヘイト撤廃 と民主化運動の闘士である。彼女は基調報告の なかで、強力な先進国がグローバリゼーション のペースと経済発展度合いを決めている結果、 貧困と不平等が一段と深まっているとし、ネ オ・リベラルの支配を断ち切る政治と、それに もとづく政府システムの透明化がガバナンスの 確立に不可欠と強調した。

11月6日から9日には、この基調報告のもとに $\lceil I$ 情報化時代における持続可能な成長と開 発」、「II説明責任・透明性・効率性をそなえた 信頼される行政をめざして」、「III行政能力の強 化と成長・開発に向けた人的資源の活用」、「IV 持続可能な開発政治のための国際組織と国内行 政の関連性」の4つのワークショップが開かれ た。サブトピックスの力点の抢かれ方は異なっ ているものの、これらのワークショップの議論 には、かなりの共通性があった。公務員制度の あり方が問題とされるとともに、意思決定シス テムに打ける市民や国際的組織との協働をいか に確保するかが重要とされ、それぞれの国の経 験と現在の改革課題が率值に披露された。

\section{成功したアジア・アフリカパネル}

こうしたワークショップとは別に、日本から の参加者5名が中心となったアジア・アフリカ パネルが、11月8日に開催された。テーマは 「国内開発のための政府とNGOのワークシェア リング・協働」であり、片岡宽光・国際行政学 会執行委員 (早稲田大学大学院教授) が議長を務 めた。このパネルでは、インド、タイ、フイリ ッピンの参加者が報告を行うとともに、会場と の間で活発な議論が展開された。

日本国内での政府 (行政) とNPO・NGO との 協働をめぐって推進論がある一方で、両者に多 くの齟齠もみられる。まったく同様に、インド やフィリピンにおいても、両者の関係は順調一 色ではなく、相互不信といった状況も説明され た。

ともあれ、持続可能な成長に向けたガバナン スの向上にとって、こうした協働がひとつの重 要なキイである。その意味で、片岡寛光教授を リーダーとしたアジア・アフリカパネルは、今 回の学会に大きく寄与できたといってよい。

新藤宗幸（しんどう むねゆき 1946年生）

第18期日本学術会議第2部政治学研究連絡委員会委員、 千葉大学法経学部教授

専門：行政学 